\title{
Vykonatelnost rozsudků Soudního dvora Evropské unie
}

\section{Enforceability of Judgments of the Court of Justice of the European Union}

\author{
Iva Fellerová Palkovská*
}

\begin{abstract}
Abstrakt
Cilem článku je analyzovat vykonatelnost rozhodnuti unijnich soudio v unijnim právu. Nejprve je predestren úcel, jaký v unijnim právu vykonatelnost plni, následnè je pozornost zaostrena na právni qakotveni tohoto

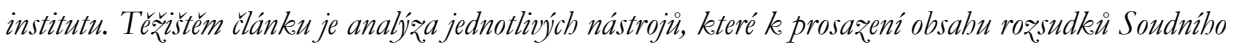
dvora EU sloǔ̌i, at' už se jedná o prímý výkon rozhodnuti nebo jiné nástroje zajištujici vykonatelnost. Závèrem lže konstatovat, že vykonatelnost je vlastnost, kterou rozsudky Soudního dvora EU mají, tedy že povinnost postupovat ve shoděs rozsudky SDEU v unijním právu platí.
\end{abstract}

\section{Klíčová slova}

Vykonatelnost rozsudkui; Soudni dvir EU; rozhodnutí Soudního dvora EU; výkon rozhodnuti; úcinky rozsudki.

\begin{abstract}
The aim of the article is to analyze the enforceability of judgments in European Union law. Firstly, the aim of enforceability of judgments in Union law is presented, subsequently, the article focuses on how the enforceability of judgments is enshrined in EU law. The central focal point of the article is the analysis of particular instruments that serve as means of implementation of judgments, be it direct enforcement of judgments or other instruments that ensure the enforcement. Overall, it may be concluded that judgments of EU courts are enforceable and therefore, the obligation to abide by CJEU judgments is a valid component of EU law.
\end{abstract}

\section{Keywords}

Enforceability of Judgments; EU Court of Justice; Decisions of the EU Court of Justice; Execution of Judgments; Effects of Judgments.

\section{Úvod}

Tento článek analyzuje vykonatelnost rozsudků Soudního dvora EU coby jednu z vlastností soudních rozhodnutí, zabývat se tedy bude tím, zda, př́padně jakými způsoby, je možné vynutit respektování soudních rozhodnutí unijních soudů a právním zakotvením těchto způsobů. Pozornost je třeba věnovat vykonatelnosti rozsudků SDEU jak vi̊či jednotlivcům, tak vưči členským státům a Unii. Vykonatelnost rozsudků SDEU je z odborného hlediska

\footnotetext{
* Mgr. Iva Fellerová Palkovská, doktorandka, Katedra mezinárodního a evropského práva, Právnická fakulta, Masarykova univerzita, Brno / Ph.D. student, Department of International and European Law, Faculty of Law, Masaryk University, Brno, Czech Republic / E-mail: 370609@mail.muni.cz
} 
zajímavá oblast, nebot' se zde otevírá řada otázek, na něž neexistuje jednoznačná odpověd'. Zároveň tomuto tématu není př́liš věnována v odborné literature pozornost, většina prací se totiž zabývá vynucováním unijního práva jako celku a nezaměřuje se specificky na vynutitelnost rozsudků Soudního dvora či Tribunálu. Obě témata spolu sice přirozeně úzce souvisí, dle mého názoru je ale na místě se na ně někdy zaměřit a prozkoumat je odděleně. Článek bude zaměřen toliko na rozsudky SDEU, tedy nikoli na jiné druhy rozhodnutí. ${ }^{1}$

V tomto článku vycházím z toho, že vykonatelnost, tak jak je dále definována, je vlastností rozsudků SDEU. Tuto skutečnost doložím na tom, že unijní právo zná řadu nástrojů, které k prosazení obsahu rozsudků SDEU směřují. Zároveň představím, jak tyto jednotlivé nástroje $\mathrm{k}$ vynutitelnosti rozhodnutí slouží, jelikož většina z nich není na vynucení soudních rozhodnutí primárně zaměřena.

\section{Definice pojmu vykonatelnost}

Česká právní věda definuje pojem vykonatelnosti jako možnost přímé vynutitelnosti rozhodnutí, podle druhu rozsudku se může jednat o možnost realizace výkonem rozhodnutí (u rozhodnutí na plněnî), u ostatních druhů rozhodnutí se bude jednat o povinnost postupovat ve shodě s rozhodnutím. ${ }^{2}$ Vykonatelnost v českém pojetí nelze zaměňovat s možností nařízení výkonu rozhodnutí a jeho samotným výkonem. Podle českého pojetí je vykonatelnost obecnou vlastností rozhodnutí - všechna soudní rozhodnutí jsou vykonatelná, rozdíl je v tom, jakým zpơsobem. ${ }^{3}$

Např́klad německé a rakouské pojetí vykonatelnosti je od toho českého rozdílné, jelikož vykonatelnost je vlastní pouze rozsudkům na plnění, tedy těm, u nichž přichází do úvahy výkon rozhodnutí, rozsudky určovací a jiné vykonatelnosti nenabývají. ${ }^{4}$ Pojem vykonatelnosti je tedy spjat pouze se samotným výkonem v užším slova smyslu (exekucî), nikoli s jinými způsoby donucení.

1 Rozsudky jsou rozhodnutími meritorními a zpravidla se jimi řízení končí (s výjimkou rozsudků, jimiž se rozhoduje jen o části nároku), mají proto oproti usnesením větší význam. Posudky Soudního dvora mají sice značnou důležitost, na počet jich je ale nemnoho. Rozsudky tedy přirozeně tvoří páteř rozhodovací činnosti SDEU, tento článek se proto omezuje na zkoumání jejich vykonatelnosti. Vykonatelnost jiných druhů rozhodnutí může námětem pro další články.

2 LAVICKÝ, Petr. Komentáŕ k \161. In: LAVICKÝ, Petr a kol. Občanský soudní rád: Praktický komentár. Praha: Wolters Kluwer, 2016, s. 788-789; STAVINOHOVÁ, Jaruška a Petr LAVICKÝ. Základy civilního procesu. Brno: Masarykova univerzita, 2009, s. 290; SVOBODA, Karel. Občanský soudní rád: komentár. 2. vyd. Praha: C. H. Beck, 2017, komentář k \161; POTĚŠIL, Lukáš a kol. Soudni rád správní: komentár. Praha: Leges, 2014, komentář k \54, s. 480-481.

3 DVOŘÁK, Bohumil. Právni moc civilních soudních rozhodnutí: procesni studie. Praha: C. H. Beck, 2008, s. 75-76.

4 VORWERK, Volkert a Christian WOLF (Hrsg). Beck.OKZPO. 33. vyd. München: C. H. Beck, 2019, Komentár k $\int 04$ [Vollstreckbare Endurteile], marg. č. 4-5.3; KINDL, Johann, Caroline MELLER-HANNICH a Hans-Joachim WOLF (Hrsg.). Gesamtes Recht der Zwangsvollstreckung. 3. vyd. Nomos, 2015, Komentář k \ 704 [Vollstreckbare Endurteile], marg. č. 18-20; KODEK, Georg E. a Peter G. MAYR. Zivilprozessrecht. Wien: Facultas.wuv, 2011, s. 296-297; FASCHING, Hans Walter a kol. Kommentar zu den Zivilprozeßgesetzen. 3. Band, $\int 226$ bis 460 ZPO. Wien: Manzsche Verlags - und Universitätsbuchhandlung, 2004, s. 1162. 
Z uvedeného je patrné, že $\mathrm{v}$ pojetí vykonatelnosti $\mathrm{v}$ právních řádech různých států panují rozdíly a to v tak zásadní otázce, zda lze o vykonatelnosti hovořit jen u rozsudků na plnění nebo i u ostatních rozsudků - srovnání mezi českým a rakouským a německým pojetím tuto rozdílnost vystihuje.

Nelze opomenout zdůraznit, že na instituty unijního práva nelze pohlížet shodně jako na stejně nazývané instituty ve vnitrostátním právu.

Vykonatelnost jako taková v unijním právu jasně definovaná není. Pro účely tohoto článku bude definována podobně jako v českém právu, vzhledem ke specifikům unijního právního prostředí se totiž nejeví účelným vnímat vykonatelnost v německém pojetí.

Vykonatelnost proto bude $\mathrm{v}$ tomto článku chápana jako možnost určitým způsobem prosadit obsah rozhodnutí, je spojena s povinností rozhodnutí respektovat a řídit se jím.

Vykonatelnost se $\mathrm{v}$ prostředí státu standardně realizuje prostřednictvím státní moci. Unie státní mocí nedisponuje, musíme proto hovořit o realizaci prostřednictvím pravomocí Unie.

Vykonatelnost obsahově (a zpravidla také časově) navazuje na právní moc rozhodnutí je-li rozhodnutí pravomocné, konečné, bývá také vykonatelné. Z hlediska obsahového vykonatelnost v podstatě právní moc doplňuje, protože zaručuje, že konečné a závazné rozhodnutí bude také realizováno. Z hlediska časového vykonatelnost na právní moc také navazuje. Vykonatelnost rozhodnutí stejně jako právní moc výslovně upravena ve Smlouvách, Statutu SDEU ani jednacích rádech obou soudů upravena není. Je nutno vyjít $z$ ustanovení jednacích řádơ ${ }^{5}$, podle nichž se rozsudky stávají závaznými dnem vyhlášení. V den vyhlášení nabývají právní moci ${ }^{6}$ a zároveň vykonatelnosti. ${ }^{7}$ Od této chvíle mají účastníci řízení povinnost se jím řídit a od této chvíle je možné využít některého z nástrojů pro zajištění vykonatelnosti rozsudku.

\section{2 Účel vykonatelnosti}

Definiční znak vykonatelnosti, tj. možnost prosadit rozhodnutí, je zároveň i jejím účelem. $\mathrm{V}$ individuální rovině (ve vztahu $\mathrm{k}$ účastníkům řízenî) je účelem vykonatelnosti zajistit, že rozhodnutí bude realizováno. Účelem soudního řízení není poskytovat účastníkům nevykonatelná dobrozdání, účelem je poskytnout ochranu oprávněným zájmům účastníků řízení a zaručit, že se účastníci soudnímu rozhodnutí podřídí.

5 Čl. 91 Jednacího řádu Soudního dvora (dále jen ,JŘSD“) a čl. 121 Jednacího řádu Tribunálu (dále jen ,JŘT").

6 S výjimkou rozsudků Tribunálu, proti nimž je př́ípustný opravný prostředek k Soudnímu dvoru ty nabývají právní moci bud' uplynutím lhůty k podávní opravného prostředku, nebo pak v souvislosti s vyřizením opravného prostředku Soudním dvorem.

7 Opravný prostředek proti rozhodnutí Tribunálu nemá odkladný účinek, vykonatelnost tedy nastane dnem vyhlášení rozsudku Tribunálu, at’ je podán opravný prostředek či nikoli. Podobně svázaná je vykonatelnost s právní mocí také podle české úpravy správního soudního procesu. KOCOUREK, Tomáš. Komentář k \54. In: KÜHN, Zdeněk, Tomáš KOCOUREK a kol. Sondní rád spráuní: Komentár. Praha: Wolters Kluwer, 2019, s. 457. 
V obecné rovině je účelem vykonatelnosti rozsudků SDEU „zajistit účinné poư̌zivání práva [Unie]"8 jako celku. Vědomost účastníka řízení, že obsah rozsudku může být vynucen i proti jeho vůli, může ve vztahu k účastníkovi působit preventivně a směřovat jej k dobrovolnému přizpůsobení se rozsudku a zvyšovat tak dodržování unijního práva. Možnost prosadit rozhodnutí je také jedním z prvků, který zvyšuje autoritu Soudního dvora EU.

Institut vykonatelnosti je sice $\mathrm{v}$ právních řádech členských států konstruován různě, možnost rozhodnutí soudu určitým zpơsobem prosadit vưči účastníkům řízení je nerozlučně spjata se soudním rozhodnutím všude, v opačném př́ípadě by byl popřen smysl soudního rozhodnutí jako takového a ostatně práva jako takového.

Právo je ex definitione spojeno s možností donucení. Donucení je zpravidla uskutečňováno prostřednictvím státní moci (v případě vnitrostátního práva). ${ }^{9} \mathrm{~V}$ tomto ohledu je situace v Unii odlišná - Unie státní mocí nedisponuje. Z části se opírá o státní moc svých členských států, kromě toho má také vlastní mechanismy zajištění vynutitelnosti rozhodnutí SDEU. Použití těchto mechanismů je možné vưči Unii a vůči členským státům (ve vztahu k jednotlivcům jsou využívány nástroje vnitrostátního práva). Jednotlivé nástroje mohou být $\mathrm{k}$ dispozici Unii, členským státům nebo jednotlivcům.

$\mathrm{V}$ tomto ohledu je tedy $\mathrm{v}$ unijním právu specifikem oproti vnitrostátnímu právu rovněž to, že je potřeba uvažovat, že otázka prosaditelnosti rozsudků SDEU bude vyvstávat nejen mezi státem a jednotlivci, ale mezi Unií, státem a jednotlivci ve všech myslitelných směrech.

\section{Právní úprava vykonatelnosti}

Obecným zakotvením vykonatelnosti rozsudků Soudního dvora EU je zásada loajální spolupráce zakotvená v čl. 4 odst. 3 SEU, podle níž se členské státy a Unie navzájem respektují a pomáhají si při plnění úkolů vyplývajících ze Smluv, členské státy mají také činit veškerá vhodná opatření k plnění závazků, které vyplývají ze Smluv či z aktů orgánů Unie. V tomto ustanovení je tedy výslovně zakotvena povinnost členských států postupovat v souladu s akty orgánů Unie, mezi něž radíme také rozsudky SDEU.

Zásada loajální spolupráce je jednou ze základních zásad ovládajících unijní právo. Značný význam této zásady vyzdvihuje často také Soudní dvůr, označil ji za ,podstatný

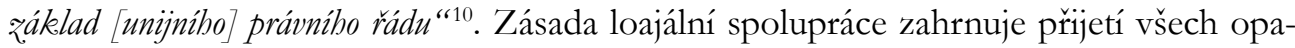

8 Rozsudek Soudního dvora (velkého senátu) ze dne 12. července 2005, Komise Evropských společenstvi proti Francouzské republice, věc č. C-304/02, odst. 80.

9 BOGUSZAK, Jiří, Jiř́ ČAPEK a Aleš GERLOCH. Teorie práva. Praha: ASPI Publishing, 2004, s. $29-31$.

10 Rozsudek Soudního dvora ze dne 7. února 1973, Komise Evropských společenství proti Italské republice, věc č. 39-72, odst. 25. Citováno dle KAHL, Wolfgang. Komentář k čl. 10 SES. In: CALLIES, Christian a Matthias RUFFERT (eds.). EUV/EGV: Das Verfassungsrecht der Europäischen Union mit Europäischer Grundrechtscharta. München: C. H. Beck, 2007, s. 429. 
tření k tomu, aby unijní právo bylo v členských státech aplikováno jednotně a účinně a vyžaduje zapojení moci zákonodárné, výkonné i soudní. ${ }^{11}$

Adresátem zásady loajální spolupráce je kromě členských států také Unie. ${ }^{12}$ Jednotlivci naopak z této zásady vázáni nejsou, na základě tohoto ustanovení jim nemohou vznikat povinnosti. ${ }^{13}$

Zásada loajální spolupráce mezi Unií a členskými státy je skutečně tím nejobecnějším vyjádřením povinnosti respektovat rozsudky SDEU, která je dále konkrétněji zdůrazněna i na dalších místech ve Smlouvách. Skutečnost, že nerespektování rozsudků SDEU je porušením také zásady loajální spolupráce, má podstatný důsledek spočívající v tom, že nerespektování rozsudků SDEU bude považováno za závažné porušení povinnosti plynoucí z unijního práva na straně subjektu, který se porušení dopustil (stát nebo Unie), právě z toho důvodu, že zásada loajální spolupráce je jedním ze základních ústavních principů unijního práva. Závažnost porušení pak hraje roli při posuzování povinnosti k náhradě škody a při navrhování výše pokuty v žalobě Komise proti členskému státu v řízení o porušení povinnosti.

Pojem vykonatelnost obsahuje čl. $280 \mathrm{SFEU}^{14}$, nijak ale neupřesňuje, co se vykonatelností rozumí, ani tento pojem blíže nerozvádí. Odkazuje pouze na čl. 299 SFEU, který obsahuje úpravu výkonu rozhodnutí unijních rozsudků. Je tedy otázkou, zda pojem vykonatelnost obsažený v ustanovení čl. 280 SFEU má zahrnovat pouze možnost výkonu rozhodnutí na plnění (podobně jako v německém či rakouském pojetî), nebo zda chápe vykonatelnost jako obecnou vlastnost rozhodnutí (podobně jako v českém pojetî) a na čl. 299 SFEU odkazuje pouze pro případy výkonu rozhodnutí na plnění, přičemž na jiné zpơsoby vykonatelnosti zachycené ve Smlouvách sice výslovně neodkazuje, ale počítá s nimi. V každém př́padě je možné čl. 280 SFEU vnímat jako potvrzení toho, že přinejmenším rozsudky na plnění vykonatelné jsou, jelikož je pro ně výslovně stanovena možnost výkonu.

$\mathrm{V}$ př́padě rozsudků jiných než na plnění spočívá jejich vykonatelnost v prosazení rozsudku jinými způsoby. K tomu dochází prostřednictvím různých mechanismů, které jsou blíže popsány v části páté tohoto článku. Závaznost rozsudků SDEU, tj. povinnost řídit se jimi, plyne ze samotného principu právní moci rozsudku. Tato povinnost je zesílena tím, že je pro některé situace výslovně zakotvena rovněž ve SFEU. Dále na ni navazuje vykonatelnost, tedy možnost autoritativního prosazení rozsudku i proti vůli jeho adresáta.

11 KAHL, 2007, op. cit., s. 429-430.

12 Rozsudek Soudního dvora ze dne 10. února 1983, Lucemburské velkovévodství proti Evropskému parlamentu, věc 230/81, odst. 37-38. Citováno dle: KAHL, 2007, op. cit., s. 463.

13 HATJE, Armin. Komentář k čl. 4 odst. 3 SEU. In: SCHWARZE, Jürgen (ed.). EU Kommentar. 4. vyd. Nomos, 2019, s. 71.

14 „Rozsudky Soudního dvora Evropské unie jsou vykonatelné qa podminek stanovených v článku 299." 
Povinnost řídit se rozsudky SDEU je ve SFEU zakotvena pro rozsudky vydané v řízení o porušení povinnosti členským státem, které deklarují pochybení na straně členského státu. $\mathrm{V}$ tomto případě Smlouvy přikazují členskému státu přijmout opatření plynoucí z rozsudku Soudního dvora. ${ }^{15}$ Povinnost odstranit pochybení na straně členského státu má stát jako celek, dle okolností tato povinnost může ležet na moci zákonodárné (přijetí, změna či zrušení právního předpisu), výkonné (změna správní praxe) či soudní (zohledňování judikatury SDEU při rozhodovánî). ${ }^{16}$

Ve vztahu $\mathrm{k}$ unijním institucím je povinnost následovat rozsudky SDEU vyjádřena v čl. 266 SFEU. Tato povinnost leží na té instituci, jejíž jednání (ve formě individuálního nebo normativního aktu nebo nečinnosti) bylo prohlášeno za protiprávní. Dle okolností proto bude spočívat $\mathrm{v}$ určitém jednání instituce, která byla soudem označena za nečinnou, v případě zrušeného aktu bude spočívat ve vydání nového aktu, který již nebude stižen vadou, jež byla soudem vytknuta, př́ípadně v nevydání aktu, byl-li tento nezákonný, př́padně chybí-li dané instituci pravomoc jej vydat. ${ }^{17}$

\section{Př́mý výkon rozsudků na plnění}

\subsection{Výkon rozsudků SDEU vůči členským státům}

Co se týče výkonu rozhodnutí na peněžité plnění, otázky vzbuzuje praktická možnost Unie vymoci placení pokuty po členském státu, pokud by uložené částky stát nezaplatil dobrovolně. To přichází do úvahy zejména $\mathrm{v}$ návaznosti na rozsudky vydané $\mathrm{v}$ řízení o porušení povinnosti podle čl. 260 SFEU. Na tuto otázku se názory v literatuře liší. ${ }^{18}$ Odpověd' je nutno hledat především v čl. 280 SFEU ve spojení s čl. 299 SFEU. Jejich výklad ale není zcela jednoznačný. Dle čl. 280 SFEU jsou rozsudky Soudního dvora EU vykonatelné za podmínek stanovených v čl. 299 SFEU ${ }^{19}$ - ten obsahuje pravidla výkonu rozhodnutí Rady, Komise nebo Evropské centrální banky, jež jsou určené jiným osobám než státům. Jednoznačné není to, zda se čl. 280 SFEU odkazuje pouze

15 Čl. 260 odst. 1 SFEU.

16 CREMER, Wolfgang. Komentář k čl. 228 SES. In: CALLIES, RUFFERT, op. cit., s. 1999.

17 Ibid., s. 2053.

18 Viz názory citované Thewesem. THEWES, Christian. Bindung und Durchsetzung dergerichtlichen Entscheidungen in der EU. Hamburg: Verlag Dr. Kovač, 2003, s. 292.

19 „Akty Rady, Komise nebo Evropské centrálni banky, které ukládaji penéžitý závazele jiným osobám než státuim, jsou podkladem pro výkon roz̧odnutí.

Výkon roz̧hodnuti se rúdi predpisy občanskébo procesního práva toho státu, na jehož územi se provádí. Doložku vykonatelnosti prïpoji po prezkoumání rozhodnutí, omezeném jen na ovéreni pravosti, vnitrostátní orgán, keterý k tomu urú vláda každého členského státu; jeho uř́eni dá na védomi Komisi a Soudnímu dvoru Evropské unie.

J sou-li na žádost oprávnèné strany splnèny tyto formální náležitosti, mưže tato strana v souladu s vnitrostátním právem požádat o výkon rozhodnuti prímo prìslušný orgán.

Výkon rozhodnutí mưze být zastaven pouze na základě rozhodnutí Soudního dvora Evropské unie. Kontrola rádného provádèni výkonu roz̧odnuti však spadá do pravomoci vnitrostátnich soudnich orgánü." 
na druhý až čtvrtý odstavec čl. 299, které obsahují pravidla pro výkon rozhodnutí, anebo i na jeho první odstavec, který právě výkon rozhodnutí neumožňuje. Přikláním se k tomu, že se odkaz použije pouze ve vztahu k pravidlům pro výkon, jelikož první odstavec čl. 299 SFEU označuje za vykonatelná v něm vyjmenované akty, zatímco rozsudky Soudního dvora jsou vykonatelné už dle čl. 280 SFEU samy o sobě. Dále by závěr o použitelnosti prvního odstavce čl. 299 pro výkon rozsudků SDEU šel proti účelu právní úpravy ve Smlouvách - nebylo by př́liš logické, kdyby Smlouvy udělily SDEU pravomoc ukládat rozsudkem povinnost zaplatit určitou částku a zároveň tuto povinnost nechaly bez př́mé možnosti ji vynutit. ${ }^{20}$

Výkon peněžité povinnosti by se tedy dle čl. 299 SFEU měl uskutečnit podle předpisů občanského práva procesního toho státu, v němž k výkonu dochází, což bude zpravidla ten stát, vưči němuž bude třeba výkon provést. Tato možnost je sice teoreticky možná, ale budí řadu otázek, na které je obtížné odpovědět, např́klad jak by se postupovalo $\mathrm{v}$ případě, že by orgány státu exekuci vưči vlastnímu státu prostě nenařídily, př́padně pokud by sice nařídily, ale následně ji zastavily at' už z důvodů hmotněprávních či procesních. ${ }^{21}$ Pokud by nebyla př́slušná částka vymožena, mohla by Komise zahájit nové řízení o porušení povinnosti, to by ale mohlo nakonec skončit úplně stejně. Vedení takového řízení by postrádalo jakýkoli smysl.

Jako alternativa se nabízí možnost Komise započíst pohledávku oproti platbám z fondů EU. Otázka, je-li takový postup možný, není rovněž vůbec jasná.

Lze se setkat s názorem, že je tato varianta vyloučena, jelikož pro ni ve Smlouvách nelze nalézt právní základ. ${ }^{22}$ Tento argument sám o sobě je nutné odmítnout, protože Smlouvy jsou neustále se vyvíjejícím nástrojem a řada věcí v nich není výslovně zakotvena, a přesto byla Soudním dvorem dovozena a je všeobecně akceptována jako platná (typicky přednost unijního práva, přímý a nepruímý účinek, odpovědnost typu Francovich). Častější je opačný názor, a sice že započtení oproti platbám z fondů EU je možný způsob výkonu rozhodnutí vůči členským státům. ${ }^{23} \mathrm{~V}$ této souvislosti bývá poukazováno na skutečnost, že Soudní dvůr možnost započtení pohledávek v rámci plateb z fondů EU uznal. ${ }^{24}$ Nelze ale odhlédnout od toho, že se jednalo o započtení mezi Unií a podnikem, nikoli členským státem. Nezodpovězenou otázkou tudíž zůstává, zda lze závěr z tohoto rozsudku

20 Shodně např. s Thewesem a Thielem. THEWES, op. cit., s. 294-295; THIELE, Alexander. Europäisches Prozessrecht. 2. vyd. München: C. H. Beck, 2014, s. 93-94.

21 HUMMER, Waldemar. Finanzielle Sanktionen gegen Mitgliedstaaten bei Nichterfüllung von EuGHUrteilen. In: HUMMER, Waldemar (ed.). Neueste Entwicklungen im Zusammenspiel von Europarecht und nationalem Recht der Mitgliedstaaten. Wien: SpringerWienNewYork, 2010, s. 601.

22 HÄRTEL, Ines. Durchsetzbarkeit von Zwangsgeld-Urteilen des EuGH gegen Mitgliedstaaten. Europarecht, 2001, sešit 4, s. 623.

23 THEWES, op. cit., s. 296; THIELE, op. cit., s. 94.

24 HUMMER, op. cit., s. 602; Rozsudek Soudního dvora ze dne 10. července 2003, Komise Evropských společenstvi proti Conseil des communes et régions d'Europe (CCRE), věc C-87/01 P a další v něm citované. 
analogicky aplikovat $i$ na prípady sankčního započtení mezi státy a Unií, prípadně za jakých podmínek by bylo možné započtení provést, zda by bylo možné započítávat pokuty oproti platbám z jakýchkoli fondů nebo zda se daly započítat pouze platby $\mathrm{z}$ fondů, $\mathrm{z}$ nichž je podporována oblast, $\mathrm{v}$ niž $\mathrm{k}$ porušení došlo - napríklad že by pokutu za porušení unijního práva životního prostředí bylo možné započítat oproti platbám z fondů na ochranu životního prostředí, nikoli třeba oproti platbám z fondu podporujícím zaměstnanost $\mathrm{v}$ méně rozvinutých regionech. ${ }^{25}$

Pokud se týká výkonu rozhodnutí na jiné než peněžité plnění, přichází do úvahy výkon rozhodnutí vydaných $\mathrm{v}$ rízení o porušení povinnosti (bez uložení pokuty) nebo $\mathrm{v}$ rízení o předběžných otázkách. Pro př́mý výkon těchto rozhodnutí se mechanismus dle čl. 299 SFEU nehodí, je proto namístě využít mechanismů neprúmého výkonu rozhodnutí, které jsou popsány v části páté tohoto článku.

\subsection{Výkon rozsudků SDEU vůči Unii}

Také Unie může být rozsudkem zavázána $\mathrm{k}$ zaplacení určité finanční částky, např́ílad z titulu náhrady škody. Je na jednu stranu málo pravděpodobné, že by se ostatní orgány a instituce Unie odmítly podřídit rozsudku Soudního dvora či Tribunálu, jelikož by tím vyslaly signál o absenci povinnosti respektovat rozsudky SDEU, čímž by došlo k značnému oslabení Unie jako celku a vymahatelnosti unijního práva. Nicméně toto je spíše pragmaticko-politický důvod, nikoli právní a je proto zcela namístě se ptát, zda je výkon rozhodnutí vůči Unii prípustný či nikoli.

Je nutno vyjít z Protokolu o výsadách a imunitách Evropské unie, konkrétně z jeho čl. 1 třetí věty, která uvádí, že „majetek a pobledávky Unie se nemohou stát prédmètem jakébokoli výkonu správního nebo soudníbo rozhodnutí bez zmocnèni Soudního dvora". Zdá se tedy, že protokol v obecné rovině připouští výkon rozhodnutí vǔči Unii, pouze jej podmiňuje zmocněním Soudního dvora. Připouští-li tedy protokol možnost výkonu rozhodnutí vǔči Unii, Unie tedy nemá vůči nucenému výkonu rozhodnutí absolutní imunitu, nemělo by výkonu rozhodnutí z právního hlediska nic bránit. ${ }^{26}$ Výkon rozhodnutí by pak probíhal v souladu s čl. 299 SFEU podobně jako vůči členským státům.

Pokud se týká výkonu rozhodnutí vůči Unii na jiné než peněžité plnění, kterými jsou rozhodnutí vydaná $\mathrm{v}$ řízení o neplatnosti aktu a o žalobě na nečinnost, podobně jako $\mathrm{v}$ př́ípadě výkonu rozhodnutí na nepeněžité plnění vǔči státu se ani v př́ípadě výkonu vůči Unii nehodí postup dle čl. 299 SFEU. Dosáhnout realizace rozhodnutí by bylo možné díky některému z nástrojů zajišst'ujících vykonatelnost popsaných v části páté tohoto článku.

25 Härtel je toho názoru, že mezi porušením a oblastí podporovanou z fondu musí být spojitost. HÄRTEL, op. cit., s. 626.

26 Stejného názoru je např. THEWES, op. cit., s. 306-308, nebo THIELE, op. cit., s. 236-237; S výkonem rozhodnutí vưči Unii počítá i LASOK, Paul, Timothy MILLETT a Anneli HOWARD. Judicial Control in the EU: Procedures and Principles. Oxford: Oxford University Press, 2004, marg. č. 305. 


\subsection{Výkon rozsudků SDEU vůči jednotlivcům}

Na rozdíl od vymahatelnosti vưči Unii či členským státům v tomto případě není pochyb o tom, že vymáhat rozsudky SDEU ukládající jednotlivcům peněžité plnění, je možné SFEU s tím přímo počítá.

Již zmiňovaný čl. 299 SFEU je původně určen právě pro výkon rozhodnutí vůči jednotlivcům. Právní úprava zde předpokládá, že výkon bude proveden v některém z členských států podle jeho práva; Unie totiž nemá vlastní mechanismy, které by umožnily př́mý výkon rozhodnutí vưči jednotlivcům, jelikož nedisponuje státní mocí. Tímto způsobem je možné provádět výkon jak peněžitých, tak nepeněžitých plnění. Rozsudek SDEU je exekučním titulem, výkon rozhodnutí v členském státě bude proto probíhat standardním způsobem obdobně jako výkon rozhodnutí vnitrostátních soudů s tím rozdílem, že v rámci vykonávacího řízení nemohou vnitrostátní orgány nijak přezkoumávat věcnou správnost rozsudku SDEU, určený orgán státu pouze ověří pravost rozsudku a připojí k němu doložku vykonatelnosti. Zastavení výkonu rozhodnutí je rovněž mimo pravomoc vnitrostátních orgánů, je k němu oprávněn SDEU. ${ }^{27}$

\section{Nástroje zajišt'ující vykonatelnost rozsudků SDEU}

Níže jsou popsány jednotlivé nástroje zajišt'ující vykonatelnost rozsudků SDEU, které je možné uplatnit ve vztahu ke všem druhům rozsudků SDEU. Na tyto nástroje můžeme nahlížet z několika úhlů.

Jako první se nabízí nahlížení na jednotlivé nástroje podle toho, zda užití daného nástroje vede prrímo k zajištění souladu s rozsudkem SDEU nebo zda je jejich cílem nepřímé donucení. Přímo k zajištění souladu vede řízení na neplatnost aktu (souladu je zde dosaženo zrušením aktu) podobně jako zrušení vnitrostátního rozhodnutí v instančním postupu, dále také řízení o porušení povinnosti běžné i jeho sankční forma (jeho hlavním cílem není deklaratorní výrok soudu, že členský stát porušil unijní právo, resp. rozsudek ukládající členskému státu zaplacení pokuty, ale zajištění správné aplikace unijního práva), a uplatnění prrímého či nepřímého účinku před vnitrostátním soudem. Mezi nepřímé nástroje pak bude patřit žaloba na náhradu škody vưči členskému státu nebo Unii, žaloba na nečinnost nebo řízení o předběžných otázkách. Tyto nástroje nesměřují sice přímo na odstranění jednání nesouladného s dřívějším rozsudkem SDEU, ale mohou přesto přispět $\mathrm{k}$ tomu, že závadný stav bude napraven. Je ale potřeba zároveň říci, že jediným mechanismem prrímo předvídaným Smlouvami vưči členským státům ${ }^{28}$, který je přímo určený pro případy, kdy se strana, která neuspěla ve sporu, odmítá podřídit rozsudku Soudního dvora, je řízení o porušení povinnosti členským státem podle čl. 260 odst. 2

27 Čl. 299 SFEU, bliže viz SCHOO, Johann. Komentář k čl. 299. In: SCHWARZE, Jürgen (ed.). EU Kommentar. 3. vyd. Nomos, 2014, s. 2387.

28 Vůči jednotlivcům SFEU předpokládá výkon rozhodnutí dle čl. 280 a 299 SFEU, vůči Unii výslovně určený mechanismus Smlouvy nezakotvují. 
SFEU. Ostatní nástroje už jsou určeny primárně pro vynucování unijního práva obecně, ale dají se uplatnit i v př́padech, kdy dotčený subjekt nepostupuje v souladu s rozsudkem SDEU.

Nástroje můžeme také rozdělit podle toho, zda k jejich uplatnění dochází na unijní úrovni nebo na úrovni členských států. Na unijní úrovni je možné využít řízení o porušení povinnosti, sankční i běžné, žalobu na nečinnost, žalobu na náhradu škody vưči Unii a žalobu na neplatnost aktu. Na úrovni členských států se nabízí zrušení rozhodnutî $\mathrm{v}$ instančním postupu, uplatnění přímého nebo nepřímého účinku, žaloba na náhradu škody vůči členskému státu a řízení o předběžných otázkách.

\section{1 Ř́zení o porušení povinnosti podle čl. 260 odst. 2 SFEU}

Rízení podle čl. 260 odst. 2 SFEU ${ }^{29}$, tzv. sankční řízení o porušení povinnosti, je jediným čistě unijním instrumentem, který je přímo zaměřen na vynucování obsahu rozsudků Soudního dvora EU. Navazuje na první odstavec čl. 260 SFEU, podle něhož je členský stát povinen přijmout opatření vyplývající z rozsudku Soudní dvora, pokud Soudní dvůr konstatuje, že členský stát porušil povinnost plynoucí ze Smluv.

$\mathrm{V}$ prrípadě, že členský stát povinnost vyplývající z rozsudku Soudního dvora nesplní, může Komise podat k Soudnímu dvoru žalobu. Toto řízení je speciálním druhem řízení o porušení povinnosti. ${ }^{30}$ Oproti standardnímu řízení má určitá specifika. I v tomto řízení má Komise nejprve zaslat členskému státu formální upozornění, v němž bude uvedeno, které povinnosti plynoucí z rozsudku členský stát dle Komise nesplnil. Formální upozornění proto má významnou roli spočívající v tom, že ohraničuje předmět řízení. Členský stát má možnost se bránit a Komisi vysvětlit, že povinnost ve skutečnosti plní nebo osvětlit důvody, proč je neplní. Na rozdíl od běžného řízení o porušení povinnosti Komise nevydává odůvodněné stanovisko a může rovnou podat žalobu Soudnímu dvoru. ${ }^{31}$ Tímto způsobem je řízení urychleno a je tak zvýšena i jeho efektivita - díky tomu je v průměru dříve vydán rozsudek Soudního dvora, který může členskému státu uložit peněžitou sankci, díky čemuž je členský stát motivován protiprávní stav odstranit ci nejdříve.

29 „Má-li Komise za to, že dotyćný členský stát neprijal opatreni, která vyplývaji z rozsudku Soudního dvora Evropské unie, může predložit věc Soudnímu dvoru Evropské unie poté, co poskytla tomuto státu prúle žitost se vyjádruit. Navrhne paušální částku nebo penále, ježje dotyčný členský stát povinen zaplatit, ve výsí, kterou považuje za primérénou okolnostem.

Shledá-li Soudní dvůr Evropské unie, že dotyčný členský stát nevyhověl jeho rozsudku, může mu uložit zaplacení paušální částky nebo penále.“

30 THIELE, Carmen. Sanktionen gegen EG-Mitgiledstaaten zur Durchsetzung von Europäischen Gemeinschaftsrecht - Das Sanktionsverfahren nach art. 228 Abs. 2 EG. Europarecht, 2008, sešit 3, s. 326. Dostupné z: http://www.Beck-online.de

31 Vypuštění fáze odůvodněného stanoviska bylo do Smlouvy zavedeno Lisabonskou smlouvou. Předlisabonská úprava tohoto řízení se prakticky od běžného řízení o porušení povinnosti nelišila. ANDERSEN, Stine. The Enforcement of EU Law: The Role of the European Commission. Oxford: Oxford University Press, 2012, s. 102-104. 
Je nutno poznamenat, že řízení podle druhého odstavce čl. 260 SFEU má od běžného řízení o porušení povinnosti odlišný předmět. Předmětem tohoto speciálního řízení již není porušení povinnosti, kvưli kterému se vedlo běžné řízení o porušení povinnosti, nýbrž nepřijetí opatření plynoucí z dřívějšího rozsudku. ${ }^{32}$

Řízení o porušení povinnosti (ani běžné ani pro nepřijetí opatření vyplývajících z dřívějšího rozsudku) není svou povahou řízením trestním ani správnětrestním. ${ }^{33}$

Negativním následkem spojeným s rozsudkem pro nepřijetí opatření vyplývajících z dřívějšího rozsudku je pokuta uložená Soudním dvorem. Pokuta může mít formu jednorázové paušální částky nebo periodicky se opakujícího se penále, nebo kombinaci obojîho. Účelem pokuty ve formě paušální částky je sankce, která je dostatečně závažná, aby působila preventivním a odrazujícím účinkem, aby se členským státům nevyplatilo s plněním povinnosti čekat až na druhý odsuzující rozsudek Soudního dvora. Odráží také dopad na soukromé a veřejné zájmy délku porušení do doby výpočtu pokuty. Účelem pokuty ve formě penále je donucení státu k co nejrychlejšímu splnění povinnosti, protože penále je uloženo do doby splnění původního rozsudku. ${ }^{34}$

Motivačním (ve smyslu směřujícím ke splnění povinnosti členským státem) je také způsob stanovení výše pokuty ${ }^{35}$. Komise pro výpočet pokuty stanovila mechanismus, který zohledňuje tři základní faktory -závažnost porušení unijního práva, délku jeho trvání a potřebu, aby pokuta měla odrazující účinek. Samotný výpočet vychází ze základní částky, která je fixní (každoročně je upravována podle výše inflace, Komise částku pro daný rok vždy zveřejní formou sdělení Komise) a liší se pro výpočet paušální částky a penále. Tato částka je vynásobena koeficientem 1 až 20 podle závažnosti porušení, a dále koeficientem 1 až 3 podle doby trvání porušení. Odrazující účinek je zajištěn tak, že se částka následně vynásobí koeficientem, který odráží platební schopnost konkrétního státu tak, že zohledňuje HDP daného státu a váhu jeho hlasů při hlasování v Radě. ${ }^{36}$ Soudní dvưr se sice od návrhu Komise může při stanovení výše pokuty odchýlit a to v obou směrech ${ }^{37}$, nicméně i sám Soudní dvůr uznal návrh Komise v obecné rovině

32 THEWES, op. cit., s. 262; THIELE, op. cit., s. 322.

33 Stanovisko generální advokátky - Kokott - 28 ledna 2010, Evropská komise proti Lucemburskému velkovévodství, věc č. C-526/08.

34 Rozsudek Soudního dvora (velkého senátu) ze dne 12. července 2005, Komise Evropských společenství proti Francouzské republice, věc č. C-304/02, odst. 81; Také viz PEERS, Steve. Sanctions for Infringement of EU Law after the Treaty of Lisbon. European Public Law, 2012, roč. 18, č. 1, s. 36.

35 Ten Komise zpracovala ve sdělení Komise o aplikaci článku 228 Smlouvy o ES, SEC (2005) 1658, upraveném později sdělením Komise o aplikaci článku 260 Smlouvy o fungování EU, SEC (2010) 923/3, každoročně aktualizovaném co se týče částek pro výpočet paušální částky a penále, koeficientu ,n'a minimální paušální částky (poslední aktualizace proběhla sdělením Komise ze dne 18. 9. 2018 C(2018) 5851.

36 Blíže viz ANDERSEN, op. cit., s. 108, nebo podrobněji THIELE, op. cit, s. 336-342.

37 Tj. může ji zvýšit nebo snížit. Ve věci Komise proti Francii, č. C-304/02, Soudní dvůr uložil Francii hradit jak penále, které navrhovala Komise, tak paušální částku, kterou Komise vůbec nenavrhovala. Viz také THIELE, op. cit., s. 330 . 
jako užitečný výchozí bod ${ }^{38}$. Sám podle nich postupuje ale jen někdy - v některých př́ipadech v rozsudcích výši pokuty odůvodňuje za pomocí týchž kritérií jako Komise ${ }^{39}$, v jiných ji stanoví dle svého uvážení bez bližšího vysvětlení ${ }^{40}$.

Cílem tohoto řízení je v co nejkratší době donutit členský stát ke splnění povinnosti, která mu plyne z prvně vydaného rozsudku o porušení povinnosti. Proto je z řízení vypuštěna fáze odůvodněného stanoviska, také kombinace paušální pokuty a penále a způsob výpočtu výše pokuty Komisí umožňuje Komisi a Soudnímu dvoru reagovat na aktuální př́pad a zvolit druh a výši pokuty, které nejúčinněji zajistí plnění povinností členským státem.

\section{2 Ř́zení o porušení povinnosti podle čl. 258 SFEU}

Obecné řízení o porušení povinnosti se jako způsob vykonatelnosti rozhodnutí SDEU uplatní $\mathrm{v}$ prrípadech, kdy dřivější rozhodnutí nebylo vydáno v řízení o porušení povinnosti proti danému státu, ale proti jinému státu, nebo se jednalo o jiný druh řízení, typicky o ř́zení o předběžné otázce. Pokud členský stát systematicky nerespektuje judikaturu Soudního dvora, porušuje tím unijní právo, na což může Komise reagovat zahájením řízení o porušení povinnosti a případně následně podáním žalobu k Soudnímu dvoru.

Je lhostejné, zda se porušování unijního práva dopouští legislativa, exekutiva nebo soudy, na možnosti Komise vést ř́zení o porušení povinnosti a Soudního dvora konstatovat porušení unijního práva na straně státu to nic nemění. ${ }^{41}$

Následkem odsuzujícího rozsudku Soudního dvora je povinnost členského státu přijmout všechna opatření, která jsou potřebná proto, aby bylo porušení unijního práva napraveno. Rozsudek je deklaratorní, Soudní dvůr v něm neuvádí, jakým způsobem se má členský stát zachovat, která konkrétní opatření má přijmout - v tomto směru má členský stát prostor pro uvážení. ${ }^{42}$ Ač Smlouva nestanovuje lhůtu, do kdy má členský stát opatření přijmout, panuje shoda, že by tak měl učinit v co nejkratší možné době. ${ }^{43}$

38 Rozsudek Soudního dvora ze dne 4. července 2000, Komise proti Řecku, věc C-287/97, odst. 89.

39 Viz např̀. rozsudek Soudního dvora (prvního senátu) ze dne 14. listopadu 2018, Evropská komise v. Reckáa republika, věc C-93/17.

40 Např. rozsudek Soudního dvora (pátého senátu) ze dne 17. října 2013, Evropská komise proti Belgickému království, věc C-533/11, odst. 62; Viz také PRETE, Luca. Infringement Proceedings in EU Law. Alphen aan den Rijn: Wolters Kluwer, 2017, s. 263.

41 Čl. 260 SFEU. Rozsudek Soudního dvora (prvního senátu) ze dne 28. června 2001, Gervais Larsy proti Institut national d'assurances sociales pour travailleurs indépendants (INASTI), věc C-118/00; Rozsudek Soudního dvora ze dne 9. prosince 2003, Komise Evropských společenstvi proti Italské republice, věc C-129/00; Stanovisko generálního advokáta - Geelhoed - 3 června 2003, Komise Evropských společenství proti Italské republice, věc C-129/00, odst. 53; Také viz KOTZUR Markus. Komentář k čl. 258 SFEU. In: GEIGER, Rudolf, Daniel-Erasmus KHAN a Markus KOTZUR (eds.). European Union Treaties: Treaty on European Union, Treaty on the Functioning of the European Union. München: C. H. Beck, 2015.

42 KOTZUR Markus. Komentář k čl. 260 SFEU. In: GEIGER, KHAN, KOTZUR, op. cit.

43 CREMER, Wolfgang. Komentár k čl. 228 SES. In: CALLIES, RUFFERT, op. cit. 
Komise sleduje, jaká opatření členský stát přijal, a pokud shledá, že nejsou dostatečná, může se rozsudek stát podkladem pro navazující rízení o porušení povinnosti ve smyslu čl. 260 odst. 2 SFEU.

Komise má sice diskreční pravomoc v tom směru, že nemusí podávat žalobu k Soudnímu dvoru kvưli každému porušení Smluv, které zjistí, ${ }^{44}$ což může na první pohled působit jako faktor snižující efektivní prosazování unijního práva, ve skutečnosti to může působit naopak - Komisi to může pomoci zaměřit se na případy závažného porušování unijního práva a ty pak sledovat a usilovat v nich o nápravu, přičemž porušování unijního práva následující poté, co Soudní dvưr v řízení o předběžné otázce nebo o porušení povinnosti stanovil, jaký je správný výklad unijního práva, je Soudním dvorem považováno jako závažné. ${ }^{45}$

Účelem řízení o porušení povinnosti vedením Komisí ale není dovést spor před Soudní dvůr, účelem je docílit toho, aby unijní právo jako celek (včetně rozsudků Soudního dvora podávajících výklad unijního práva) bylo dodržováno. Snahou Komise tedy je vyjasnit si situaci s členským státem co nejdříve, pokud možno ještě během neformální fáze. ${ }^{46}$ Vyjednávání s členským státem je vedle formálních nástrojů nezbytnou součástí dohledu Komise nad tím, že členské státy plní své povinnosti plynoucí ze Smluv. ${ }^{47}$ Efektivitu postupu Komise můžeme doložit skutečností, že většina zahájených řízení o porušení povinnosti skončí ve fázi před podáním žaloby ${ }^{48} \cdot{ }^{49}$

\section{3 Ř́zení na neplatnost aktu}

Není-li respektován rozsudek Soudního dvora EU tím, že je přijat právní akt, at' už normativní nebo individuální povahy, který je s dřívějším rozsudkem SDEU v rozporu, je možné jej napadnout žalobou na neplatnost aktu.

Podmínky pro prŕpustnost žaloby na neplatnost aktu jsou rozdílné podle toho, kdo je žalobcem a jaký akt je napadán. ${ }^{50}$ Privilegovaní žalobci (členské státy, Parlament, Rada, Komise) mohou podat žalobu na neplatnost bez dalších omezení, Účetní dvůr, Evropská centrální banka a Výbor regionů, je-li to potřeba k ochraně jejich práv. Jednotlivci mohou

44 Čl. 258 druhý pododstavec SFEU.

45 PEERS, op. cit., s. 50.

46 THIELE, op. cit., s. 74.

47 TAllbERG, Jonas. Paths to Compliance: Enforcement, Management, and the European Union. International Organization, 2002, roč. 56, č. 3, s. 618; CRAIG Paul a Gráinne DE BÚRCA. EU law: text, cases, and materials. 4. vyd. Oxford: Oxford University Press, 2008, s. 432.

48 TALLBERG, op. cit., s. 617.

49 Byt' je potřeba uvést, že ne ve všech případech bude důvodem úspěch vyjednávání s členským státem, může se jednat také o př́pady, kdy Komise ukončí řízení před podáním žaloby z politických důvodů, nebo proto, že porušení unijního práva na straně členského státu shledá jako bagatelní apod.

50 Čl. 263 SFEU. 
žalobu na neplatnost aktu podat, pokud napadají individuální akt, jehož jsou adresátem. Co se jiných aktů týče, jsou jednotlivci aktivně legitimováni, jen pokud napadají akt, který se jich bezprostředně a individuálně týká, nebo akt s obecnou působností, které se jich bezprostředně dotýkají a nevyžadují přijetí prováděcích opatření. ${ }^{51}$

Žaloba na neplatnost aktu může coby nástroj vynucení rozsudku SDEU přicházet do úvahy například v situaci, kdy Soudní dvưr zruší legislativní akt, v odůvodnění rozsudku uvede, v čem nezákonnost aktu spočívala, a unijní normotvưrce následně přijme nový legislativní akt, který bude zatížen stejnou vadou. $\mathrm{V}$ případě individuálních aktů platí totéž obdobně.

Žaloba na neplatnost aktu coby nástroj vynutitelnosti rozsudků SDEU je nástrojem efektivním z toho pohledu, že je-li žalobě vyhověno, napadený akt je prohlášen za neplatný a nevyvolává již dále právní účinky. Je proto zcela zásadní pro zajištění a kontrolu legality v unijním právu a pro ochranu práv subjektů unijního práva.

\section{4 Žaloba na nečinnost}

Tato žaloba je $\mathrm{k}$ dispozici v případech nečinnosti na straně orgánů a institucí Unie, uplatnit ji mohou jak ostatní unijní instituce, členské státy, tak jednotlivci' ${ }^{52}$ Obecně je př́ipustná, pokud orgán či instituce Unie je nečinný, ač měl povinnost konat.

Žalobu na nečinnost jakožto nástroj zajištění vykonatelnosti rozsudků SDEU je možné využít $\mathrm{v}$ prrípadech, kdy prríslušná instituce Unie nepřijme opatření plynoucí z dřívějšího rozsudku. ${ }^{53}$

Řízení o žalobě na nečinnost bývá dáváno do dvojice s řízením na neplatnost aktu coby dvě strany jedné mince, jelikož mírí ve své podstatě obě na odstranění protiprávního jednání na straně Unie. Ve srovnání s rozsudkem prohlašujícím neplatnost aktu, díky němuž napadený akt přestává platit a vyvolávat právní následky, nemá žaloba konstatující nečinnost žádný srovnatelný efekt, Soudní dvưr ani Tribunál nemají oprávnění na místo př́islušné unijní instituce požadovaný akt přijmout. ${ }^{54}$

51 TÝČ, Vladimír. Základy práva Evropské unie pro ekonomy. 7. vyd. Praha: Leges, 2017, s. 129-131; KACZOROWSKA, Alina. European Union law. 2. vyd. London: Routledge, 2011, s. 429-458.

Judikatura a literatura věnující se tématu aktivní legitimace jednotlivců k podání žaloby na neplatnost je bohatá, tato problematika prošla značným vývojem, k určitému zmírnění podmínek aktivní legitimace jednotlivců došlo Lisabonskou smlouvou. KACZOROWSKA, op. cit., s. 423.

52 Za splnění dalších podmínek, jako je např. výzva dotčenému orgánu k nápravě, u jednotlivců je potřeba také prokázat, že se nevydané rozhodnutí a tím pádem i nečinnost unijní instituce žalobce bezprostředně a osobně týká, podobně jako u žaloby na neplatnost aktu. Čl. 265 SFEU; viz také MONIZ, Carlos Botelho. Overview of the Mechanisms of Enforcement of Community Law. In: Enforcing community law from Francovich to Köbler: Twelve years of the state liability. 2004, s. 27; LENAERTS, Koen, Ignace MASELIS a Kathleen GUTMAN. EU Procedural Law, Oxford: Oxford University Press, 2014, s. 420.

53 MONIZ, op. cit., s. 32.

54 LENAERTS, GUTMAN, MASELIS, op. cit., s. 426 a 439-440. 
Praktický význam žaloby na nečinnost pro vynutitelnost rozsudků SDEU bude spíše malý. Vyhovující rozsudek má deklaratorní povahu, SDEU v rozsudku neukládá žádná konkrétní opatření, která by měla prríslušná instituce př̀ijmout, a ač je povinnost odstranit Soudem konstatovanou nečinnost do určité míry zabezpečena čl. 266 SFEU $^{55}$, ani toto ustanovení samo o sobě ukončení nečinnosti nezaručí.

Hmatatelný význam bude mít rozsudek v řízení o žalobě na nečinnost jako podklad pro řízení o náhradě škody vưči Unii nebo př́imo ve spojení těchto dvou řízení. ${ }^{56}$ Další význam žaloby na nečinnost může být také mimoprávní, spočívající ve vytvoření určitého tlaku na nečinnou unijní instituci.

\subsection{Odpovědnost za škodu}

Jako nepřímý donucovací mechanismus k plnění rozsudků SDEU slouží také povinnost k náhradě škody. Odpovědnost může vzniknout jak na straně Unie ${ }^{57}$, tak na straně členských států ${ }^{58}$.

Mimosmluvní odpovědnost Unie je založena čl. 340 SFEU, podle něhož se odpovědnost Unie řídí obecnými zásadami společnými právním řádům členských států. Odpovědnost členského státu za škodu jednotlivci způsobenou porušením unijního práva dovodil Soudní dvůr v rozsudku Francovich ${ }^{59}$.

Pro formulování podmínek vzniku odpovědnosti za škodu byla v obou případech podstatná především judikatura Soudního dvora, přičemž dlouhou se judikatura k těmto dvěma typům odpovědnosti vyvijela samostatně, podmínky pro vznik odpovědnosti se proto lišily. Po rozsudku Soudního dvora ve věci Bergaderm ${ }^{60}$ se obě linie judikatury sjednotily - SDEU se vyslovil, že podmínky pro uplatnění mimosmluvní odpovědnosti Unie by se neměly lišit od podmínek pro uplatnění odpovědnosti členského státu za porušení práva EU. Judikatura k odpovědnosti členského státu za porušení práva

55 Čl. 266 SFEU: „Orgán, instituce nebo jiný subjekt, jehož akt byl problášen za neplatný nebo jehož nečinnost byla prohlásena za odporujici Smlouvám, je povinen prijmout opatreni vyplývajici z rozsudku Soudníbo dvora Evropské unie. Tato povinnost se netýká povinností, které mohou vyplynout zpouřití cl. 340 drubébo pododstavce."

56 MONIZ, op. cit., s. 32.

57 Podrobně k mimosmluvní odpovědnosti Unie viz MALÍř, Jan. Mimosmluvní odpovědnost EU: Dekonstrukce jednoho institutu. Prárník, 2012, č. 6.

58 PRETE, op. cit., kap. S 4.02; PRECHAL, Sacha. Member State Liability and Direct Effect: What's the Difference After All? European Business Law Review, 2006, roč. 17, č. 2.

59 Ač Soudní dvůr poprvé připustil povinnost států k náhradě škody způsobené unijním právem již v rozsudku Russo v roce 1976, za rozsudek přinášející tento institut do unijního práva je tradičně označován právě rozsudek Francovich.

Rozsudek Soudního dvora ze dne 22. ledna 1976, Carmine Antonio Russo proti Azienda di Stato per gli interventi sul mercato agricolo (AIMA), věc 60-75 a rozsudek Soudního dvora ze dne 19. listopadu 1991, Andrea Francovich a Danila Bonifaci a dalši proti Italské republice, spojené věci C-6/90 a C-9/90.

60 Rozsudek Soudního dvora ze dne 4. července 2000, Laboratoires pharmaceutiques Bergaderm SA a Jean-Jacques Goupil proti Komisi Evropských společenství, věc C-352/98. 
Unie počínající rozsudkem Francovich se tak použije i při posuzování odpovědnosti Unie a stejně to platí naopak.

Co se týče podmínek pro nastoupení odpovědnosti, v prvé řadě se jedná o protiprávnost jednání, ta musí spočívat v porušení právní normy, která přiznává právo jednotlivcům. Dále je potřeba, aby porušení bylo dostatečně závažné. Přri posuzování závažnosti porušení je potřeba brát do úvahy také míru uvážení, kterou v daném případě orgán měl $\mathrm{v}$ př́padech, kdy orgán neměl vůbec nebo měl jen minimální prostor pro uvážení, každé porušení je zároveň porušením dostatečně závažným. ${ }^{61}$ Naproti tomu v případech, kde je př́slušný orgán nadán větším prostorem pro uvážení, je nutno prokázat skutečně závažné porušení práva EU. ${ }^{62}$ Nutným předpokladem odpovědnosti je také vzniknuvší újma a přirozeně také prŕčinná souvislost mezi protiprávním jednáním a vznikem újmy. ${ }^{63}$ Podmínky pro vznik povinnosti nahradit škodu jsou v praxi vykládány poměrně přísně. ${ }^{64}$ Nejobtížněji naplnitelným kritériem je obvykle podmínka dostatečné závažnosti porušení. Vzhledem k tomu, že Soudní dvưr prohlásil nerespektování svých dř́vějších rozsudků za dostatečně závažné ${ }^{65}$, neměla by tato podmínka uplatnění nároku na náhradu škody zpo̊sobené nerespektováním rozsudku SDEU členským státem, případně Unií, bránit žalobci v úspěchu, pokud na základě předchozího rozsudku mu vzniklo určité právo, př́padně pokud rozsudek jeho právo potvrdil, prokáže-li zároveň vznik újmy a príćinnou souvislost.

Odpovědnost Unie nebo členského státu za škodu je konstruována jako odpovědnost vưči jednotlivci, je proto otázkou, zda by se Unie mohla domáhat náhrady škody vůči státu, nebo členský stát vưči Unii. V rozsudku Komise proti Itálii Soudní dvůr takovou možnost naznačil, když uvedl, že odsuzující rozsudek v řízení o porušení povinnosti může být základem odpovědnosti daného státu ve vztahu k ostatním členským státům, Unii nebo jednotlivcům. ${ }^{66}$ Žádnou takovou žalobou se ale SDEU zabývat nemusel, je proto otázka, zda by taková žaloba byla skutečně uznána jako př́pustná. Thiele je toho názoru, že by žaloba členského státu k náhradě škody měla být př́pustná, protože i členské státy jsou podřízeny Unii a musí se řídit akty unijních institucí, v důsledku čehož může státům

61 Rozsudek Soudního dvora ze dne 4. července 2000, Laboratoires pharmaceutiques Bergaderm SA a Jean-Jacques Goupil proti Komisi Evropských společenství, věc C-352/98, odst. 44.

62 Rozsudek Soudního dvora ze dne 4. července 2000, Laboratoires pharmaceutiques Bergaderm SA a Jean-Jacques Goupil proti Komisi Evropských společenství, věc C-352/98, odst. 43.

63 Rozsudek Soudního dvora ze dne 4. července 2000, Laboratoires pharmaceutiques Bergaderm SA a JeanJacques Goupil proti Komisi Evropských společenství, věc C-352/98, odst. 42; MONIZ, op. cit., s. 47-50; KACZOROWSKA, op. cit., s. 476-480.

64 MALÍŘ, op. cit.

65 PEERS, op. cit., s. 50.

66 Rozsudek Soudního dvora ze dne 7. února 1973, Komise Evropských společenství proti Italské republice, věc 39-72, odst. 11; Citováno dle THEWES, op. cit., s. 253. 
vzniknout škoda. Budou-li pak např́klad prohlášeny za neplatné, bylo by nepřiměřené požadovat po členských státech, aby takovou škodu nesly samy. ${ }^{67}$

Povinnost k náhradě škody sice sama o sobě nezaručí, že primární povinnost plynoucí z rozsudku bude splněna, dotčené osobě ale nahradí ztrátu a zaručí tak, že strana, která se rozsudkem neřídí, ze svého jednání nebude mít prospěch. Možnost žádat po členském státu nebo Unii náhradu škody je díky tomu významným prvkem zaručujícím vykonatelnost rozsudků SDEU.

\section{6 Ř́zení o předběžných otázkách}

Ř́zení o předběžných otázkách ${ }^{68}$, ač to není jeho primárním účelem, může také sloužit jako nástroj nepř́ímo sloužící prosazení rozsudků SDEU v členských státech. Je to relativně jednoduchý způsob, který mají jednotlivci k dispozici.

Užitečným nástrojem bude zejména tehdy, kdy se jednotlivec bude chtít dovolávat toho, že právní úprava nebo soudní praxe v členském státě je v rozporu s dřívějším rozsudkem SDEU, lhostejno v jakém typu řízení byl vydán a jestli se týkal stejného členského státu či jiného. Předloží-li vnitrostátní soud rozhodující spor předběžnou otázku, může se Soudní dvưr adresně vyjádřit ke správnému výkladu konkrétní právní úpravy a utvrdit tím výklad, který již dříve poskytl. Rozhodnutí o předběžné otázce je pro předkládající soud, stejně jako pro soudy rozhodující spor v rámci instančního postupu, závazné. ${ }^{69}$ Vedle toho je s rozhodnutím o předběžné otázce spojena povinnost členského státu uvést v soulad vnitrostátní právo s unijním tak, jak bylo vyloženo Soudním dvorem ${ }^{70}$, obdobná povinnost platí i pro Unii ${ }^{71}$.

Význam řízení o předběžných otázkách pro vývoj unijního práva je neoddiskutovatelný, dobře zdokumentovaný je ale i jeho význam pro prosazování unijního práva ${ }^{72}$. Kromě toho, že může pomoci vymoci jeho právo individuálnímu žalobci, slouží Komisi jako cenný indikátor dodržování či nedodržování unijního práva členskými státy - díky svému právu účastnit se všech řízení o předběžných otázkách před Soudním dvorem,

67 THIELE, op. cit., s. 229-230.

68 Čl. 267 SFEU.

69 Rozsudek Soudního dvora ze dne 24. června 1969, Milch-, Fett-und Eierkontor GmbH proti Hauptzollamt Saarbrücken, věc 29-68; Rozsudek Soudního dvora ze dne 3. února 1977, Luigi Benedetti proti Munari F.lli s.a.s., věc 52-76.

70 Rozsudek Soudního dvora (prvního senátu) ze dne 21. června 2007, Office national des pensions proti Emilienne Jonkman, věc C-231/06, Hélène Vercheval, C-232/06, a Nö̈lle Permesaen proti Office national des pensions, C-233/06. Spojené věci C-231/06 až C-233/06, odst. 37; rozsudek Soudního dvora (pátého senátu) ze dne 7. ledna 2004, The Queen, na žádost Delena Wells proti Secretary of State for Transport, Local Government and the Regions, věc C-201/02, odst. 64 a 65.

71 BROBERG, Morten. Preliminary References as a Means for Enforcing EU Law. In: JAKAB, András a Dimitry KOCHENOV (eds.). The Enforcement of EU Law and Values. Oxford: Oxford University Press, 2017, s. 107.

72 BROBERG, op. cit., s. 99-100 a tam citovaná další literatura. 
se Komise dozvídá informace o uplatňování unijního práva v členských státech. Tallberg $\mathrm{v}$ této souvislosti mluví o řízení o předběžné otázce jako o požárním alarmu, který Komisi upozorňuje na problémy s aplikací unijního práva v členských a částečně také Komisi odbřemeňuje. ${ }^{73}$

Pokud se týká vztahu řízení o porušení povinnosti a řízení o předběžné otázce, navzájem se oba typy řízení doplňují a vedení jednoho druhu řízení není na překážku druhému druhu řízení, i když se týkají stejné právní úpravy. ${ }^{74}$ Představují totiž různé způsoby dosažení téhož cíle.

\subsection{Zrušení soudního rozhodnutí v instančním postupu}

Pokud vnitrostátní soud nerespektuje judikaturu Soudního dvora, nesprávně aplikuje unijní právo. ${ }^{75}$ Nejčastěji se bude nerespektování judikatury SDEU spočívat v nerespektování rozhodnutí o předběžných otázkách, at' už vydané v rámci právě projednávaného sporu nebo vydané dříve $\mathrm{v}$ jiném řízení, může ale spočívat i v nerespektování rozsudků SDEU vydaných $\mathrm{v}$ jiných druzích řízení, např. řízení o porušení povinnosti vưči kterémukoli členskému státu. Pokud je řízení zatíženo takovouto vadou, obecně může být $\mathrm{v}$ instančním postupu zrušeno. ${ }^{76}$ Chybná aplikace judikatury tak může být rychle a jednoduše zhojena na vnitrostátní úrovni.

\subsection{Přímý a nepřímý účinek unijního práva}

K nepřímému vymožení obsahu rozsudku SDEU je také možné využít institut př́imého ${ }^{77}$ či nepřímého ${ }^{78}$ účinku unijního práva. ${ }^{79}$ Rozsudky SDEU sice samy o sobě př́mý, resp. neprrímý účinek do vnitrostátního práva mít nemohou, jelikož nejsou právními normami, potvrzují ale správný výklad unijních právních norem ${ }^{80}$, které pak už přímý nebo nepřímý účinek mít mohou.

73 TALLBERG, op. cit. s. 622.

74 Broberg a Fenger uvádí příklad dvou řízení o porušení povinnosti a jednoho řízení o předběžné otázce, která se všechna shodně týkala implementace směrnice o odpovědnosti za škodu způsobenou vadou výrobku, přičemž všechny tři rozsudky byly vyhlášeny ve stejný den. BROBERG, Morten P. a Niels FENGER. Preliminary references to the European court of justice. 2. vyd. Oxford: Oxford University Press, 2014, s. 212.

75 BROBER, FENGER, op. cit., s. 453.

76 NAÔMÉ, Caroline. Prejudiciálna otáz̨ea v európskom práve: Praktický sprievodca. Z originálu Le renvoi prejudicial en droit européen: Guide Pratique přeložil Ján Mazák. Bratislava: Iura Edition, 2011, s. 210; BOBEK, Michal a kol. Predběžná otázkea v komunitárním právu. Praha: Linde, 2005, s. 233 a 394; THEWES, op. cit., s. 245.

77 Rozsudek Soudního dvora ze dne 5. února 1963, NV Algemene Transport - en Expeditie Onderneming van Gend \& Loos proti Nederlandse administratie der belastingen, věc 26-62.

78 Rozsudek Soudního dvora ze dne 10. dubna 1984, Sabine von Colson a Elisabeth Kamann proti Land NordrbeinWestfalen, věc $14 / 83$.

79 MONIZ, op. cit., s. 44.

80 Interpretace práva předchází jeho aplikaci, tedy nejen řízení o předběžných otázkách, i v jiných typech ř́zení je unijní právo vykládáno. 
Pokud je unijní právní norma dostatečně jasná, přesná a bezpodmínečná a pokud jsou splněny i další podmínky pro uplatnění přímého, resp. nepřímého účinku, může se jej jednotlivec dovolat ve správním či soudním řízení na vnitrostátní úrovni. ${ }^{81}$

Podobně jako $v$ prrípadě řízení o předběžné otázce je uplatnění prrímého či neprrímého účinku významným prvkem decentralizace vymáhání práva. Díky tomu jsou účinné především pro jednotlivce, protože nejefektivněji vyřeší jejich individuální prrípad. Uplatnění přímého, resp. nepřímého účinku a řízení o předběžné otázce často půjde ruku v ruce vnitrostátní soud podá předběžnou otázku, Soudní dvůr podá výklad ustanovení unijního práva a vysloví jeho prrímý účinek, resp. sdělní vnitrostátnímu soudu, že má vnitrostátní právo co nejvíce vykládat eurokonformně, a tímto pak bude zaručena ochrana práv jednotlivce. Nicméně tyto dva způsoby vymáhání mohou být uplatněny i samy o sobě - přímý i neprrímý účinek může být soudem i jiným orgánem přiznán některému ustanovení unijního práva i bez toho, aby se soud obrátil s předběžnou otázkou na Soudní dvůr. Zároveň žádost o rozhodnutí o předběžné otázce může být podána i ve vztahu k jiným otázkám než k otázce přímého či nepřímého účinku některého ustanovení unijního práva.

\subsection{Mechanismus dle čl. 7 SEU}

Jako další z mechanismů vynucování unijního práva pro zajištění vykonatelnosti rozsudků SDEU se nabízí postup dle čl. 7 SEU. Toto ustanovení zakotvuje sankční mechanismus sloužící ochraně základních hodnot a principů, na nichž je postavena Unie. Tyto hodnoty jsou vypočteny v čl. 2 SEU. ${ }^{82}$

Z výčtu je patrné, že se jedná o základní principy vnitřního fungování právního státu, nejedná se tedy o principy př́mo související se zapojením státu do Unie a jeho spoluprací s Unií ostatními členskými státy. Primárně je tedy zaměřen na vnitřní záležitosti státu a porušování principů právního státu bez př́mé vazby na konkrétní povinnost plynoucí z unijního práva (z primárního práva, sekundárních aktů nebo rozhodnutí SDEU). Pro nedodržování povinností státem ve vztahu $\mathrm{k}$ Unii nebo k jiným členským státům z titulu členství v Unii je totiž primárně určeno řízení pro porušení povinnosti.

Možnost využít čl. 7 SEU sice přichází do úvahy i v př́padě nerespektování rozsudků SDEU, muselo by ale mít značný systémový rozměr. Nestačilo by tedy nerespektování jednotlivého rozsudku SDEU, ale o déle trvající nerespektování většího množství rozsudků, případně nerespektování judikatury SDEU vůbec. Tato možnost je tedy spíše teoretická, jelikož postup pro tento účel použit nikdy nebyl, ani o něm nebylo uvažováno. Pro porušování unijního práva se více hodí řízení o porušení povinnosti, které je pro

81 THEWES, op. cit., s. 254-255.

82 „Unie je založena na hodnotách úcty ke lidské dìstojnosti, svobody, demokracie, rovnosti, právního státu a dodržování lidských práv, včetně práv prǐslušnikè menšin. Tyto hodnoty jsou společné členským státuim ve společnosti vyznačujicí se pluralismem, neprípustnosti diskriminace, tolerancí, spravedlností, solidaritou a rovnosti žen a mư̌u. " 
tento účel také určeno. Ani v literatuře se o použití čl. 7 SEU pro tento účel prakticky nedočteme, protože většina autorů zabývajících se mechanismem dle čl. 7 o této eventualitě neuvažuje. ${ }^{83}$ Výjimkou je $\mathrm{v}$ tomto př́padě Hummer, který považuje mechanismus dle čl. 7 SEU za použitelný, nicméně pouze ve zmiňovaném systémovém rozměru značného rozsahu. ${ }^{84}$

\section{Shrnutí možného použití nástrojů zajišt'ujících vykonatelnost rozsudků SDEU}

Jak vidno z přehledu výše, nástrojů sloužících $\mathrm{k}$ vykonatelnosti rozsudků SDEU je celá řada a pro všechny druhy rozsudků (podle typů rízení, v nichž byly vydány) existuje nějaký. Rozsudky vydané $\mathrm{v}$ ř́zení o porušení povinnosti členským státem lze vymoci pomocí sankčního řízení o porušení povinnosti, $v$ němž může být členskému státu uložena pokuta. Jednotlivci se mohou dovolat přímého či neprímého účinku unijního práva a domoci se tak svého práva, které jim dle unijního práva náleží. Za tímto účelem mohou žádat vnitrostátní soud o položení předběžné otázky k Soudnímu dvoru a následné rozhodnutí může sloužit jako vodítko všem vnitrostátním soudům rozhodujícím obdobné spory, mimo to předběžná otázka upozorní Komisi na porušování unijního práva členským státem. Nepřichází-li do úvahy prímý či neprímý účinek, mají nárok na náhradu škody vůči státu, která jim vznikla v důsledku porušování unijního práva.

Pokud není respektován rozsudek vyslovující neplatnost aktu, je možné podat novou žalobu na následně vydaný akt. Ten bude opětovně zrušen, čímž bude zajištěno respektování prvně vydaného rozhodnutí.

Rozsudek konstatující nečinnost unijní instituce je možné vynutit neprímo uplatněním nároku na náhradu škody vưči nečinné instituci.

Respektování dřive vydaného rozhodnutí o předběžných otázkách je možné na vnitrostátní úrovni vynutit zrušením rozhodnutí v instančním postupu, př́padně podáním nové předběžné otázky nebo dovoláním se přímého či nepríimého účinku ustanovení unijního práva, které bylo dřívějším rozhodnutím o předběžné otázce vyloženo. Kromě toho vzniká na straně členského státu povinnost $\mathrm{k}$ náhradě škody jednotlivci a v neposlední řadě může Komise zahájit ř́zení o porušení povinnosti prosti členskému státu, který nerespektuje výklad unijního práva podaný Soudním dvorem v řízení o předběžné otázce.

A konečně rozsudky ukládající povinnost $\mathrm{k}$ plnění lze vymoci při prímém výkonu rozhodnutí, jak je popsáno ve čtvrté části tohoto článku.

83 Viz např. MONIZ, op. cit.; nebo BECKER, Ulrich. Komentář k čl. 7 SEU, s. 137-143; ve spojení s SCHWARZE, Jürgen a Nina WUNDERLICH. Komentáŕ k čl. 2. In: SCHWARZE, Jürgen (ed.). EU Kommentar. 4. vyd. Nomos, 2019, s. 51-53; př́padně publikace JAKAB, András a Dimitry KOCHENOV (eds.). The Enforcement of EU Law and Values. Oxford: Oxford University Press, 2017.

84 HUMMER, op. cit., s. 604. 


\section{Závěr}

Cílem tohoto článku bylo potvrdit, že vykonatelnost je vlastností rozsudků SDEU, a analyzovat, jakým zpo̊sobem se projevuje, tedy jakým způsobem dochází k prosazení rozsudků.

Je potřeba říci, že vykonatelnost rozsudků SDEU je otázkou velmi specifickou, projevuje se zde zvláštnost unijního práva, které je sice ve své podstatě právem mezinárodním, ale zároveň má určité vlastnosti podobné vlastnostem práva federálního, tedy vnitrostátního (především princip nadstátnosti).

Vykonatelnost jako taková je sice vlastností soudních rozhodnutí ve všech členských státech (byt' se pod tímto pojmem chápe leckdy něco jiného), nevykonatelné soudní rozhodnutí by stěží mohlo plnit svou funkci, nástroje pro zajištění vykonatelnosti se však na unijní úrovni značně liší. Unie nedisponuje státní mocí, která by jí zajišstovala exekuční aparát.

Pro zajištění, že se účastníci řízení a další subjekty rozhodnutí SDEU podřídí, existuje v unijním právu řada nástrojů.

Ve vztahu k jednotlivcům se výrazně projevuje decentralizace výkonu unijního práva, unijní právo v př́padě výkonu rozhodnutí vưči jednotlivcům spoléhá na členské státy, jejich právní řády a justiční aparát.

Co se týče výkonu rozsudků SDEU ve vztahu k členským státům a Unii, je vykonatelnost založena na zásadě loajální spolupráce, tedy zásadě ve své podstatě mezinárodněprávní. Vzhledem k tomu, že dosud nenastal případ, kdy by členský stát nebo Unie nesplnily to, co dle rozsudku SDEU měly, nelze s jistotou říci, jaké jsou skutečné možnosti nuceného výkonu.

Unijní právo také disponuje celou řadou nástrojů, které mohou k vykonatelnosti přispět více či méně neprrímo, a mohou sloužit k zajištění vykonatelnosti nejen rozsudků na plnění, jichž je na unijní úrovni na rozdíl od vnitrostátních soudů relativně minimální počet. Těchto nástrojů je řada a některé z nich jsou $\mathrm{k}$ dispozici jednotlivcům, některé Unii a některé členským státům a možnosti jejich uplatnění se liší podle konkrétní situace. Zmíněné specifikum spočívá v tom, že díky tomu, že většina unijního práva je vykonávána vnitrostátními orgány, Unie vlastní systém donucení prakticky nepotřebuje. Uplatnil by se prakticky pouze v rovině členských států a Unie, kde vztahy fungují spíše na principu spolupráce. Ale jako prevenci před zneužitím pravomoci a jako prvek posilující demokratičnost Unie i na této úrovni právní, nejen politické, mechanismy k zajištění chování podle pravidel existují. V tomto článku jsou představeny a popsány tyto mechanismy a analyzovány možnosti jejich využití ve vztahu k prosazení obsahu rozsudků Soudního dvora EU. 